\title{
Zbigniew Wójcik
}

\section{POCZĄTKI RUCHU TURYSTYCZNEGO NA WARMII I MAZURACH (1945-1951)}

Słowa kluczowe:

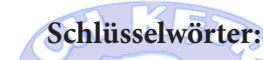

Keywords:
Tradycje turystyczne, Warmia i Mazury, walory przyrodnicze, Polskie Towarzystwo Krajoznawcze.

Touristische Traditionen, Ermland und Masuren, Naturvorteile, Polnische Gesellschaft für Heimatkunde

Tourist traditions, Warmia and Masuria, natural values, the Polish

Touring Association

\section{Zagadnienia wstępne}

Turystyka, jako jedna z form szeroko rozumianej kultury fizycznej, znacznie wyprzedziła w rozwoju sport kwalifikowany, nie tylko w regionie warmińsko-mazurskim $^{1}$. W społeczności pruskiej na przykład, głęboko zakorzeniona była tradycja polowań oraz gry i zabawy dworskie. Tak więc z pewną dozą powściągliwości, stwierdzić możemy, iż „turystykę konną” we spółczesnym rozumieniu, uprawiała już ówczesna arystokracja tej prowincji ${ }^{2}$. W czasach, kiedy rdzennie polskie ziemie znajdowały się we władaniu zaborcy, wyprawy rodaków w te strony miały natomiast charakter bardziej sentymentalny niż turystyczny ${ }^{3}$. Jednakże „poznać świat w jego naturalnych warunkach, starać się go zrozumieć, zgłębić prawa nim rządzące, pokochać otaczającą przyrodę i najbliższe środowisko oraz żyjących ludzi” ${ }^{4}$ można było na przykład w ramach szkolnej turystyki i krajoznawstwa. Dlatego też stosunkowo szybko wzrastało zainteresowanie Prusami Wschodnimi w kręgach

1 Wędrówki ludów starożytnych dały początek późniejszej turystyce. Północno-wschodnie tereny Europy jako pierwsi przemierzali Rzymianie. Powodem ich wędrówek były m.in. cele handlowe. Cesarz Neron wysyłał nawet specjalne wyprawy na ziemie plemion pruskich w celu zdobycia bursztynu, a trakt ów po dzień dzisiejszy znany jest jako „Szlak bursztynowy”. (Zob. Andrzej Gąsiorowski, Podróże historyczne i krajoznawcze na pograniczu pruskim 1466-1939, Olsztyn 2005, s. 7; Z. Wójcik, Starożytnym traktem przez Warmię i Mazury, Szkice Humanistyczne, nr 1-2, Olsztyn 2007, s. 199).

M. Dönhoff, Kindheit in Ostpreußen by Marion Gräfin Dönhoff, München 1988, ss. 59, 84.

A. Gąsiorowski, Kultura fizyczna w tradycji polskiej Warmiaków i Mazurów, Olsztyn 2008, s. 253.

4 Cyt. za A. Gąsiorowski, op. cit., s. 107. 
odkrywców i podróżników. Wspomnieć warto, że wielbicielami wędrówek po tych okolicach było wielu znamienitych Polaków, a tendencje te dobrze uosabiali pisarz, filozof i działacz społeczny Aleksander Świętochowski (1849-1938), miłośnik krajoznawstwa Mieczysław Orłowicz (1881-1959) oraz dziennikarz i publicysta Melchior Wańkowicz (1892-1974)5. Utrudnienia wprowadzane przez administrację pruską nie odstraszały światłych obywateli II Rzeczypospolitej od poznania prastarych ziem ojczystych, zwłaszcza, że dawnych tradycji i obyczajów przed zapomnieniem chronił $\mathrm{m}$. in. autor wielu publikacji ksiądz Walenty Barczewski.

Z powyższych względów Warmia i Mazury, to obszar - jak podaje A. Gąsiorowski - na którym, na gruzach plemion pruskich ścierały się dwie nie zawsze przyjazne sobie kultury: polska i niemiecka. Konflikt ten swoje apogeum osiągnął we wrześniu 1939 roku$^{6}$. Powszechnie wiadomym jest, iż jednym z jego końcowych rezultatów po zakończeniu działań wojennych był powrót utraconych przed laty terytoriów do Macierzy. Stąd też ukształtowane już tradycje i walory przyrodnicze regionu propagowali następnie już polscy osadnicy, Warmiacy i Mazurzy oraz nieliczni obywatele pochodzenia niemieckiego. Im przyszło budować zręby ruchu turystycznego, ale już pod biało-czerwonym sztandarem. Wraz z przybyciem 30 marca 1945 roku Pełnomocnika Rządu RP na Okręg Mazurski, zainicjowano proces odbudowy Krainy Tysiąca Jezior. Faktycznie jest ich w regionie ponad trzy tysiące, a powierzchnia ok. 1800 przekracza jeden hektar. Uroki Ziem Odzyskanych dość szybko zostały dostrzeżone przez wodniaków i miłośników wędrówek, choć górskie atrakcje i walory klimatyczne Morza Bałtyckiego były niemałą konkurencją. Z tego też powodu lubelscy aktywiści już w maju, wysłali na Warmię i Mazury przeszkoloną wstępnie grupę tamtejszego Hufca Ligi Morskiej, z zadaniem zabezpieczenia urządzeń nadwodnych i sprzętu pływającego. Dowódcą śmiałków był mieszkaniec Puław Henryk Kuś. Już miesiąc później wraz z instruktorem Tadeuszem Wolbekiem ich śladami podążali kolejni zapaleńcy. Choć docelowym punktem obu wypraw były położone na przesmyku między jeziorami Mamry i Niegocin Łuczany (Giżycko), to wodniacy przez miesiąc stacjonowali w czterech poniemieckich przystaniach żeglarskich nad jeziorem Ukiel (Krzywe) k. Olsztyna ${ }^{7}$

Wprawdzie młodzi aktywiści nie w pełni wywiązali się z nakreślonych zadań, ale to oni ocalili szereg urządzeń i statków pasażerskich, żaglówek, łodzi i kajaków na potrzeby późniejszej turystyki wodnej i sportu żeglarskiego. Swoją odwagą i zaangażowaniem inspirowali do działania nowych mieszkańców Warmii i Mazur.

\footnotetext{
Z. Wójcik, Turystyka, rekreacja i sport w Lidzbarku Warmińskim w czasach Polski Ludowej, Olsztyn 2014, s. 17 .

A. Gąsiorowski, op. cit., s. 333.

M. Siwicki, Edukacyjna działalność młodzieżowych ośrodków żeglarskich na Warmii i Mazurach w latach 1945-1989. Studium historyczno-pedagogiczne (praca doktorska), Olsztyn 2011, s. 152.
} 


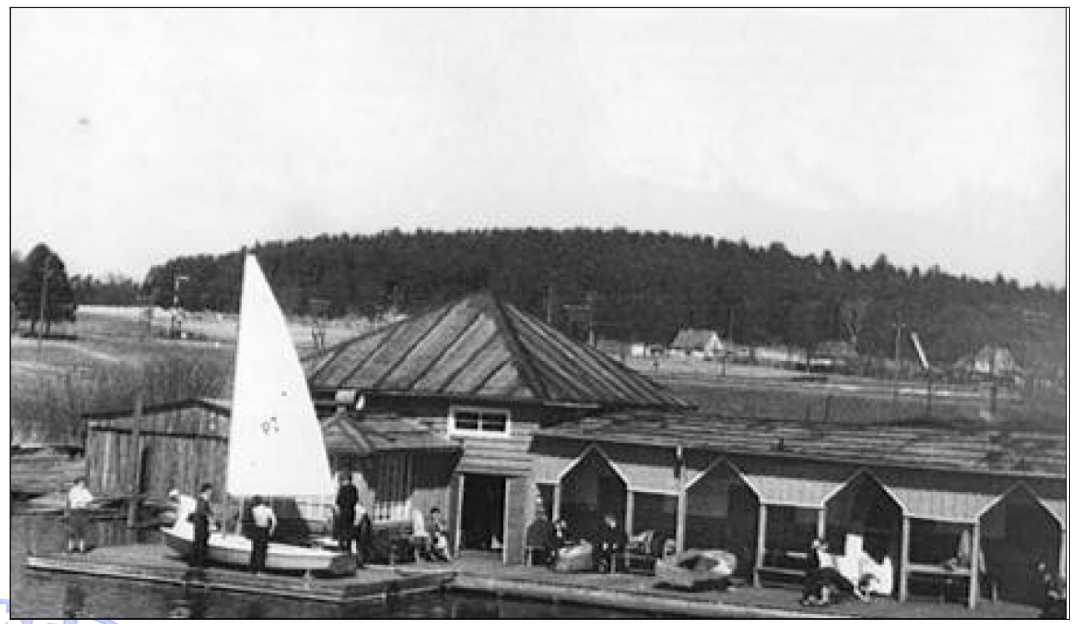

Fot. 1. Ocalała, lecz nieistniejąca już przystań żeglarska nad Jeziorem Ukiel. Widok z końca lat czterdziestych ubiegłego wieku. Źródło: M. Mazur, Warmińsko-Mazurski Okręgowy Związek Żeglarski, w: Kalendarz Olsztyna 2011, red. T. Śrutkowski, Olsztyn 2010, s. 250.

Pionierskie inicjatywy

Prusy Wschodnie dla Armii Czerwonej były pierwszym skrawkiem nazistowskich Niemiec i z tego powodu doznały większych zniszczeń niż inne terytoria. Utworzony wkrótce na Ziemiach Odzyskanych Okręg Mazurski, stał się naturalnym spadkobiercą dawnej tradycji i ocalałej infrastruktury. Mimo ogromnych strat materialnych i braku kwalifikowanych kadr, już w drugiej połowie 1945 roku, z inspiracji inżyniera Jaremy Wodzińskiego powołano Warmińsko-Mazurski Związek Turystyczny (WMZT) ${ }^{8}$. Współtworzyli go m.in.: pasjonaci turystyki motorowej bracia Mieczysław i Tadeusz Jesionowscy oraz S. Niewiarowski, K. Fijałkowski, J. Kierc i S. Zdunek. Siedziba związku mieściła się w baraku usytuowanym nad jeziorem Długim przy ulicy Bałtyckiej 1, do którego następnie wprowadził się także zarząd Olsztyńskiego Klubu Motocyklowego ${ }^{9}$. W okresie zimowym dużym nakładem społecznej pracy członków WMZT i wsparciu Zarządu Miasta wyremontowano pozostałą część baraku tworząc w ten sposób pierwsze Schronisko Turystyczne. Posiadało 150 miejsc noclegowych, ale standard ich był bardzo niski ${ }^{10}$. Działaczom turystycznym wywodzącym się z pierwszych osadników osiadłych w regionie, or-

$8 \quad$ Z. Jaczewski, Walory turystyczno-krajoznawcze województwa, Rocznik Olsztyński, t. VI, 1964, ss. 364365; Wycieczka Min. Komunikacji zwiedziła Olsztyn i najpiękniejsze okolice Warmii i Mazur, „Życie Olsztyńskie” 1947, nr 27, s. 3.

9 Olsztyński Klub Motocyklowy wśród huku piorunów rozpoczął swoją działalność, „Wiadomości Mazurskie" 1946, nr 159, s. 4.

10 Drugie schronisko turystyczne uruchomione będzie w Olsztynie, „Życie Olsztyńskie” 1947, nr 16, s. 3. 
ganizacyjnego wsparcia udzielił znawca tej problematyki, za jakiego powszechnie uchodził Mieczysław Orłowicz. Z jego inicjatywy 17 kwietnia 1946 roku w Olsztynie odbyła się konferencja poświęcona wskrzeszeniu ruchu turystycznego. Uczestniczył w niej także Pełnomocnik Rządu na Okręg Mazurski dr Zygmunt Robel. Debatowano wówczas o możliwościach uruchomienia ocalałych domów wycieczkowych, tanich schronisk i przystani żeglarskich. Postanowiono, iż z szerokiego spektrum potrzeb najpilniejszym jest: udostępnienie bazy noclegowej, wydawanie map i przewodników, pocztówek krajoznawczych, propagowanie informacji o przyrodzie, jeziorach mazurskich i zabytkach kultury ${ }^{11}$.

Olsztyńscy pionierzy zainspirowani atmosferą konferencji, wkrótce, tzn. 20 maja 1946 roku, przy dużym zaangażowaniu inż. Aleksandra Zubelewicza - naczelnika Wydziału Komunikacji w Urzędzie Pełnomocnika - powołali w stolicy przyszłego województwa oddział Polskiego Towarzystwa Krajoznawczego (PTK) ${ }^{12}$. Entuzjastom turystyki przyświecała idea: „Wrócić Warmię i Mazury Polsce, a Polskę Warmii i Mazurom". Przez szereg lat w działalności statutowej kierowano się tym patriotycznym hasłem, chcąc już na trwale związać Ziemie Odzyskane z ojczyzną. Bezpośredni „kontakt ludzi z ludźmi” jako metoda wymyślona przez Edwarda Lisiewicza, Józefa Targońskiego, Stanisława Wiśniewskiego i wspomnianego Zubelewicza były sposobem na pogłębienie procesu integracji, wspieranego również przez władze państwowe. Na podkreślenie zasługuje fakt, że patriotyzm pozostawał w ścisłym związku z rozwojem ruchu turystycznego w Polsce od czasu jego narodzin w okresie zaborów. Obowiązki prezesa PTK powierzono przedstawicielowi Kuratorium Okręgu Szkolnego magistrowi Janowi Bohuckiemu ${ }^{13}$. W codziennej działalności wspierali go członkowie zarządu, m. in.: inż. arch. Władysław Muzolf, pedagog i propagator turystyki Stanisław Wiśniewski oraz Józef Targoński, Edward Tworkowski, Zofia Kolendo, Witold Korzynek, Władysław Sienkiewicz i Aleksander Zubelewicz. Prezes Bohucki, podobnie jak J. Wodziński ściśle współpracował z referentem d/s turystyki Antonim Sarolem z Wydziału Komunikacji. Na szczególne podkreślenie zasługuje udział w pracach olsztyńskiego oddziału PTK poetki Emilii Sukertowej - Biedrawiny. W ówczesnej prasie systematycznie zamieszczała ona interesujące artykuły o zabytkach kultury, zagadnieniach etnograficznych, działaczach polskich, legendach i pieśniach Warmii i Mazur ${ }^{14}$.

11 A. Andrusikiewicz, Poznaj swój kraj i region, w: Kalendarz Olsztyna 2002, red. T. Śrutkowski, Olsztyn 2001, ss. 209-210.

12 A. Chmiel, Turystyka $w$ Polsce $w$ latach 1945-1989, Warszawa 2007, s. 255; Warmia i Mazury terenem turystyki, „Wiadomości Mazurskie” 1946, nr 112, s. 3.

13 Wraz z wspomnianymi prezesem i wiceprezesem pierwszy zarząd PTK w Olsztynie tworzyli: Jerzy Hłasko, Michał Mojsiewicz, Witold Korzynek, Edward Lisiewicz, Ferdynand Tabaka, Józef Targoński, Antoni Sarol, Bohdan Wilamowski i Stanisław Wiśniewski. (Zob. Cz. Browiński, Olsztyn 1945-1970, Olsztyn 1974, s. 199).

14 A. Andrusikiewicz, op. cit., s. 210. 
Pierwszym przedsięwzięciem nowo powstałej organizacji było zaangażowanie się wraz z WMZT w obchodzone w maju we Fromborku uroczystości ku czci Kopernika ${ }^{15}$. Wkrótce też towarzystwo przejęło w swoje władanie obiekty turystyczne w Łuczanach (Giżycku) i Mikołajkach oraz część sprzętu zabezpieczonego uprzednio przez Hufiec Ligi Morskiej ${ }^{16}$. Powyższymi przedsięwzięciami zainicjowano rozwój powojennego ruchu turystycznego w regionie. Z szacunków pracowników Urzędu Wojewódzkiego wynikało, że ok. 70 \% poniemieckich domów turystycznych, przystani i urządzeń sportowych po wykonaniu stosownych remontów nadawało się do dalszej eksploatacji. Natomiast $\mathrm{z}$ dawnych 23 hoteli jedynie w kilku można było prowadzić działalność. Ta skromna baza dzięki ofiarnej pracy działaczy WMZT umożliwiła wypoczynek i zwiedzanie Warmii i Mazur w roku 1946 ponad 30 tysiącom turystów ${ }^{17}$. Przyciągały nie tylko walory przyrodnicze tej krainy. Jak wspominała znana i ceniona działaczka Koła Przewodników Anna Andrusikiewicz wyobraźnię przyjeżdżających tu pobudzały także: „gotyckie zamki i świątynie, wielkie pałace pozostawione przez pruską arystokrację ukryte w pięknych parkach, małe miasteczka z zachowanym średniowiecznym układem urbanistycznym. Serca biły żywiej na myśl o odzyskanych polach Grunwaldu. Ciekawscy szükali moźliwo ści dotarcia do mrocznych, tajemniczych bunkrów z okresu II wojny światowej. Żeglarze z całej Polski gorąco pragnęli organizować rejsy po Wielkich Jeziorach Mazurskich, a kajakarze marzyli o wodnych szlakach przez kanały rzeczki i śródleśne ciche jeziorka"18. Właśnie na potrzeby tych marzycieli i wodniaków, PTK po wielu zabiegach - podobnie jak nieco wcześniej WMZT - wiosną 1947 roku uruchomiło nad jeziorem Długim, w baraku obok biura zarządu towarzystwa, schronisko z 60 miejscami noclegowymi ${ }^{19}$. Choć brakowało w nim kompletnego wyposażenia było drugim i już wtedy bardzo potrzebnym miejscem noclegów. Istnienie schronisk nawet o spartańskich warunkach umożliwiało sukcesywny rozwój.

Wczesną wiosną, na rekonesans po Ziemiach Odzyskanych, dwoma ciężarowymi samochodami przyjechała pierwsza, zorganizowana grupa studentów Uniwersytetu Warszawskiego. Po nich, pojawili się żacy ze stołecznej Szkoły Głównej Gospodarstwa Wiejskiego i Uniwersytetu im. Mikołaja Kopernika z Torunia. Napływ turystów w roku 1947 był już znaczny. Z tego tez powodu, jeszcze przed wakacjami, Państwowa Żegluga Śródlądowa w Giżycku zainaugurowała przewozy pasażerskie na szlakach: Giżycko - Węgorzewo i Giżycko - Mikołajki²0.

15 Uroczystości Kopernikowskie we Fromborku, „Arkona” 1945/1946, tom I, nr 8, s. 20.

16 Warmia i Mazury terenem turystyki, „Wiadomości Mazurskie” 1946, nr 112, s. 3.

17 Ibidem, s. 3.

18 A. Andrusikiewicz, Przewodnictwo turystyczne na Warmii i Mazurach, w: Przewodnictwo turystyczne w Polsce, Warszawa-Kraków 1986, s. 44.

19 Drugie schronisko turystyczne..., s. 3.

20 Coś dla turystyki. Nowe połaczenia wodne, „Życie Olsztyńskie” 1947, nr 19, s. 4. 
Wspomnieć należy, że było to nawiązanie do tradycji Prus Wschodnich ${ }^{21}$. Do oddalonego o 26 kilometrów $(\mathrm{km})$ Węgorzewa kursował dobrze wyposażony statek „Świtezianka” z 200 miejscami na pokładzie. Czas przepływu z dwoma przystankami wynosił ok. 2 godzin. Drugą linię o długości $40 \mathrm{~km}$ obsługiwał o połowę mniejszy „Mazur” oraz „Podolanin” z 80 miejscami. Pokonanie jej - z trzema przystankami - zajmowało ponad 3 godziny. W końcowej fazie były też prace remontowe na 250 osobowym parostatku „Radomianka”, który kursować miał na szlaku do Pisza ${ }^{22}$. Niewątpliwie był to spory sukces, ale przyjazdy turystów nad Niegocin ograniczała skromna baza noclegowa. Dobrze funkcjonujący hotel „Polonia” wraz z restauracją, na dom wczasów pracowniczych przejął wpływowy Związek Zawodowy Pracowników Skarbowych Rzeczypospolitej. Zarząd Miasta Giżycka nie wykazywał większej troski o turystów, choć nad Kanałem Łuczańskim funkcjonował już Centralny Ośrodek Wodny Ligi Morskiej popularyzujący żeglarstwo.

Zaradnością wykazał się natomiast WMZT przejmując do modernizacji kolejny obiekt. Podkreślić warto, że trwałyjuż prace przy naprawie urządzeń hydrologicznych na Kanale Elbląsko-Ostródzkim. Zakończenie remontu utrudniał jedynie brak stalowych lin, niezbędnych do uruchomienia platform transportujących statki lądem. Wycieczki wodnymi szlakami wielkich jezior mazurskich stanowiły nie lada atrakcję, ale liczniejsze przyjazdy zorganizowanych grup turystów hamował niedostateczny stan infrastruktury towarzyszącej. Na terenie województwa było w tym czasie ledwie 27 zakładów hotelarsko-restauracyjnych ${ }^{23}$. Pewne nadzieje wiązano z zapowiedzianą wycieczką 47 urzędników kancelarii prezydenta Rzeczypospolitej. Na dworcu niecodziennych gości oczekiwały władze miasta Olsztyna wraz $\mathrm{z}$ wicewojewodą ppłk. Tadeuszem Koralem. Przybyszy zakwaterowano w hotelach „Syrena” i „Warszawskim”. Po śniadaniu goście zwiedzali miasto i zaznajamiali się z florą i fauną okolicznych jezior. Wieczorem w teatrze Stefana Jaracza obejrzeli jeszcze sztukę „Pani Prezesowa” z popularną w tamtych latach Eugenią Śnieżko-Szafnagłową w roli głównej. W drugim dniu pobytu warszawianie odwiedzili jeszcze Mikołajki i urzeczeni regionem udali się w drogę powrotną. Wkrótce potem z kolejną wycieczką do stolicy Warmii i Mazur przyjechali pracownicy Wydziału Turystyki Ministerstwa Komunikacji. Grupą tą opiekował się oprowadzając po miejskich zabytkach i okolicy osobiście prezes WMZT, inż. Wodziński. Uroki województwa, mimo wszechobecnych uciążliwości fascynowały wielu. Odzyskaną enklawą polskości zainteresował się także minister odbudowy w rządzie Edwarda Osóbki-Morawskiego Michał Kaczorowski. Tak jak poprzedni dygnitarze odpo-

\footnotetext{
${ }_{21}$ M. Orłowicz, Ilustrowany przewodnik po Mazurach Pruskich $i$ Warmii, Olsztyn 1991, ss. 46-47.

22 Na jeziorach mazurskich ruszyły statki pasażerskie, „Życie Olsztyńskie” 1947, nr 24, s. 4.

23 Turystyka na Warmii i Mazurach pod znakiem zapytania z powodu braku pomieszczeń, „Życie Olsztyńskie" 1947 , nr 19, s. 3.
} 
czywał on wiosną 1947 roku przez kilka dni w Olsztynie i Mikołajkach ${ }^{24}$. Jednakże z obecności ówczesnych dygnitarzy partyjno-państwowych Warmia i Mazury nie miały specjalnych profitów.

Proces odbudowy z uwagi na nadal trudno osiągalne kredyty przewlekał się czasowo. Środków finansowych brakowało nawet na organizację na terenie województwa przez Ministerstwo Oświaty kolonii letnich dla sierot, półsierot, niedożywionych i zagrożonych gruźlicą dzieci. Centralne władze oświatowe przekazały odpowiedzialnej za ich przygotowanie komisji kuratoryjnej 44 miliony, natomiast personel medyczny na podstawie wcześniejszych badań zakwalifikował ponad 40 tysięcy potrzebujących ze wszystkich regionów kraju. Przybywali także harcerze. W całym sezonie, blisko 2 tysiące osób z chorągwi warszawskiej, mazowieckiej, krakowskiej, rzeszowskiej, łódzkiej i śląsko-dąbrowskiej miało swe obozowiska w rejonach Olsztyna, Szczytna i Giżycka ${ }^{25}$. Dopiero w trakcie upalnego sezonu letniego 1947 roku Zarząd Miasta Olsztyna przystąpił do wytyczania kąpielisk. Z otwartych w sumie czterech, wejście na dwa z nich było odpłatne. Przykładowo nad Jeziorem Ukiel swoistą atrakcję stanowiła wysoka wieża służąca do skoków, 3 łodzie i ponad 20 kajaków. Wczasowiczów zasmucał natomiast widok zatopionego do połowy śródlądowego statku u brzegu jeziora. Wieczory spędzano w zadaszonej sali tanecznej, gdzie na czarnym fortepianie wirtuozi wygrywali skoczne melodie. Zatrważającym był fakt, że w zasadzie na żadnym z nich nie było ratowników wodnych. Pewne zabezpieczenie stanowił jedynie surowo przestrzegany zakaz kąpieli poza miejscem oznaczonym. Tam pływać mogły jedynie osoby uprawnione. Ponadto, amatorom turystyki wodnej doskwierała niewielka ilość sprzętu pływającego oraz zaniedbane, obskurne i bez dostatecznego wyposażenia plaże w wielu miejscowościach.

\section{Rozbudowa infrastruktury}

Sukcesywnie na potrzeby ciekawskiego turysty z ruin oczyszczano także Frombork i Wzgórze Katedralne, które od chwili pobytu w mieście prezydenta Bolesława Bieruta cieszyło się jego patronatem. Jednakże napływ zwiedzających w tym czasie - tak jak na terenie całego województwa - ograniczał brak domu wycieczkowego, baru bądź restauracji. Aby choć częściowo zrekompensować niedogodności Ministerstwo Komunikacji wprowadziło uczestnikom zorganizowanych wycieczek i grup turystycznych 66 \% zniżki w drodze powrotnej z Warmii i Mazur. Obowią-

${ }^{24}$ Min. Kaczorowski spędził święta w woj. olsztyńskim, Życie Olsztyńskie” 1947, nr 27, s. 3.

251000 harcerzy olsztyńskich i 2 tysiące harcerzy-gości rozbije wkrótce namioty, „Życie Olsztyńskie” 1947, nr 43 , s. 3 . 
zywały one do 30 września w klasie trzeciej pociągów osobowych i pospiesznych z następujących stacji: Frombork, Giżycko, Kętrzyn Lidzbark, Mikołajki, Olsztynek, Olsztyn, Ostróda, Pisz, Ruciany i Węgorzewo ${ }^{26}$. Uaktywnili się także działacze PTK. Ich operatywność wynikała z częściowej realizacji obietnic złożonych przez zwiedzających wiosną województwo wysokich urzędników państwowych. Dzięki kredytowi w kwocie 400 tysięcy złotych rozpoczęto prace remontowe schronisk w Wilkasach k. Giżycka i hotelu w Mikołajkach ${ }^{27}$. Innym przejawem troski władz centralnych był przyjazd w dniu 20 lipca kilkunastoosobowej ekipy specjalistów, której przewodził dr Mieczysław Orłowicz, naczelnik Wydziału Turystyki w Ministerstwie Komunikacji. Jej naczelnym zadaniem było opracowanie na potrzeby rozwijającego się ruchu „Warmińsko-Mazurskiego Przewodnika Turystycznego”28. M. Orłowicz odgrywał w tym przedsięwzięciu wiodącą rolę, ponieważ już w roku 1923 Zjego inicjatywy ukazał się we Lwowie podobny periodyk pt. „Ilustrowany Przewodnik po Mazurach Pruskich i Warmii”. Pokłosiem zażywających relaksu na olsztyńskiej ziemi dygnitarzy państwowych był także przyjazd filmowców realizujących zdjęcia szlaków wodnych, zabytków, itp. na potrzeby Polskiej Kroniki Filmowej. Spowodowało to niewspółmierny do lat minionych napływ turystów. Natomiast Olsztyn przybyszom zaoferować mógł jedynie 350 miejsc w schroniskach, które stale były przepełnione a nowe zgłoszenia wciąż napływały. Przykładowo tylko organizacje studenckie Uniwersytetu Jagiellońskiego na okres 3 miesięcy zamówiły 30 stałych noclegów. Porównując powyższe dane z warszawskim oddziałem PTK, które w tym czasie dysponowało jedynie tysiącem miejsc w schroniskach stolicy, wysiłek olsztyńskich działaczy nabiera większego znaczenia. Baza noclegowa w regionie poprawiła się nieco po oddaniu do użytku w dniu 22 lipca pierwszego Hotelu Turystycznego Polskiego Biura Podróży (PBP) „Orbis” w Giżycku. Był to jednak obiekt o podwyższonym standardzie i przez ten fakt gościli w nim bardziej zamożni miłośnicy Mazur. Już dwa dni później zamieszkał tam akredytowany w Warszawie zespół Rady Handlowej Ambasady Brytyjskiej a wkrótce także podsekretarz stanu Ministerstwa Spraw Zagranicznych dr Stanisław Leszcycki. Ostatni z wymienionych związany był z PTK. Widoczny wzrost zainteresowania regionem umiejętnie wykorzystał prezes olsztyńskiego oddziału towarzystwa Bohucki. Wnioskując o środki finansowe na wyposażenie remontowanych schronisk otrzymał bezzwrotną dotację w kwocie 500 tysięcy złotych. Z puli tej, 100 tysięcy przeznaczono na rozbudowę infrastruktury w Olsztynie, 250 tys. na dokończenie robót w Wilkasach, a z pozostałej części (150 tys.) kontynuowano prace budowlane

\footnotetext{
26 66-procentowe zniżki wzmoga turystykę na Warmii i Mazurach, „Życie Olsztyńskie” 1947, nr, 67, s. 3.

27 Z. Wójcik, op. cit., s. 39.

28 Wielka wycieczka asów polskiej turystyki, „Życie Olsztyńskie” 1947, nr 80, s. 3.
} 
we wspomnianym już Hotelu „Warda” w Mikołajkach ${ }^{29}$. Należy podkreślić, iż były to wręcz niezbędne, ale niewystarczające inwestycje. Bez wątpienia udało się je rozpocząć dzięki zapobiegliwości gospodarzy województwa i życzliwości podejmowanych przez nich państwowych notabli.

W drugim roku powojennej działalności Warmię i Mazury odwiedziło ponad 50 tysięcy turystów, w przeważającej części młodzieży szkolnej i harcerzy. Młodzi druhowie oprócz zabawy i wypoczynku pomagali okolicznym rolnikom a $\mathrm{w}$ trakcie wędrówek zrywali bądź zamalowywali szyldy i inne ślady świadczące o poprzednich mieszkańcach tych ziem. Kwaterowali w wielu prowadzonych przez komendy obozowiskach, ale także w Schronisku Harcerskim (100 miejsc) usytuowanym w sąsiedztwie znanych już obiektów WMZT i PTK nad jeziorem Długim. Ponadto na terenie województwa funkcjonowały już podobne pensjonaty w: Mikołajkach - prowadzone przez cały sezon przez Bratnią Pomoc Szkoły Nauk Politycznych z Warszawy (70 łóżek) oraz Powszechnej Spółdzielni Spożywców w Rucianach (100 miejsc). Reprezentacyjnym obiektem z 98 miejscami sypialnymi, restauracją, kawiarnią i umilającą czas orkiestrą był natomiast wspomniany hotel „Orbis” w Giżycku. Takich atrakcji w tamtym okresie nie było jeszcze nawet W stolicy województwa, choć dobrze funkcjonująca sieć takich usług znana była już mieszkańcom Prus Wschodnich ${ }^{30}$.

W związku ze zwiększającym się zapotrzebowaniem, do planu remontów $\mathrm{i}$ adaptacji przyjęto kolejne budynki $\mathrm{w}$ terenie. Zabudowaniami nad jeziorem Drwęckim w Ostródzie zainteresował się Związek Zawodowy Dróg Kołowych, natomiast opustoszałe obiekty nad brzegiem jeziora Tałty w Mikołajkach zmodernizować postanowił WMZT ${ }^{31}$. Tak więc w roku następnym - 1948 - spodziewano się nasilenia akcji turystycznej. Zamierzeniom tym sprzyjało również stanowisko władz centralnych. Jeszcze w październiku gościł w Olsztynie Józef Dubiel z Ministerstwa Ziem Odzyskanych zainteresowany dalszym rozwojem gospodarczym regionu. Wicewojewoda Bogdan Korolewicz-Wilamowski po tym spotkaniu zobligował starostów powiatowych do przedstawienia wykazów schronisk i domów wypoczynkowych z podziałem na czynne oraz wymagające remontów, jak również wytypowania spośród dawnych majątków i dworów takich, które wykorzystać można do celów turystycznych. Niezależnie od tego do poczynienia własnych obserwacji na terenie województwa zobowiązani zostali Hieronim Skurpski z Wydziału Kultury i Sztuki oraz referent Sarol z Wydziału Komunikacji. W kooperacji

\footnotetext{
nr 105, s. 3.

500 tysięcy złotych - największą dotację w Polsce otrzymało PTK w Olsztynie, „Życie Olsztyńskie” 1947,

30 M. Orłowicz, op. cit., ss. 47-48, 51 .

31 Pięćdziesiąt tysięcy osób, oto bilans ruchu turystycznego $w$ bieżącym sezonie letnim $w$ województwie olsztyńskim, „Życie Olsztyńskie” 1947, nr 121, s. 3.
} 
z Ministerstwem Komunikacji projektowano dalszą rozbudowę linii telefonicznych, dróg i połączeń kolejowych, albowiem dojazd np. do Pisza czy Węgorzewa był tak dużym problemem jak znalezienie noclegu w tych atrakcyjnie usytuowanych miejscowościach. W końcu roku PTK otrzymało z Zarządu Głównego dotację w kwocie miliona złotych. Znaczną część tej kwoty przeznaczono na doposażenie schronisk, natomiast za 100 tysięcy złotych, na potrzeby przyszłych gości, zamówiono pływający sprzęt wodny.

Tak więc rok 1948 zaczął się bardzo optymistycznie. 11 stycznia dr Orłowicz w gmachu Gimnazjum Męskiego przy ulicy Mickiewicza w Olsztynie wygłosił odczyt „Warmia i Mazury jako teren turystyczny”. Jego kolejny przyjazd w te strony dowodził narastającego zainteresowania Ziemiami Odzyskanymi. W ramach przygotowywanej z władzami centralnymi akcji propagującej walory województwa umiejętnie wykorzystywano również zimowe atrakcje regionu, tj. łyżwiarstwo, bojery, wędkarstwo lodowe i polowania. Kreatorem takiej formy rekreacji był kierownik luksusowego hotelu w Giżycku i głównie tam przyjeżdżali zainteresowani. W połowie lutego podejmowano gości niezwykłych. Na polowanie przybył w te strony marszałek Polski Michał Rola-Żymierski w towarzystwie generałów: $\overrightarrow{P o}$ pławskiego Mossora, Zielińskiego oraz pułkowników Łędowskiego, Cepa i brata marszałka Żymierskiego. Funkcję gospodarza sprawował wiceminister leśnictwa Iwanowski, którego wspomagali wojewoda W. Jaśkiewicz z grupą najwyższych stopniem funkcjonariuszy miejscowych struktur wojska i urzędu bezpieczeństwa publicznego (płk Garbowski, ppłk Palka). Odstrzelono wówczas m. in. siedem dzików, ale najlepszym (dwa trofea) okazał się cywil - wojewoda ${ }^{32}$. Mimo tego, że województwo olsztyńskie zamieszkiwało ledwie 517300 osób, wkrótce potem, na dworcach kolejowych większych miast Polski, placówkach PBP „Orbis” i lokalach PTK ukazała się dużych rozmiarów mapa Warmii i Mazur ukazująca największe atrakcje tej krainy. Ponadto jeszcze przed sezonem dostępny był w sprzedaży długo oczekiwany przewodnik turystyczny opracowany przez Orłowicza. Zrujnowany dawny Okręg Mazurski w środowiskach krajoznawców i wędrowców znaczył coraz więcej. Upominano się nawet o niewielkie, ale związane z dawną historią Polski miejscowości. Z inspiracji Bolesława Bieruta Związek Zawodowy Historyków Kultury i Sztuki podjął działania celem zorganizowania Muzeum Mikołaja Kopernika we Fromborku. Zdumiewający był jedynie fakt, że postanowiono zdemontować wykonany jeszcze przez Niemców pomnik wielkiego astronoma. Natomiast z okazji święta Mrągowa także i w tym mieście przy ulicy Moniuszki rozpoczęto adaptację budynku na Dom Wycieczkowy. Optymizmem napawała także decyzja o uru-

32 Wielkie polowanie w lasach mazurskich $z$ udziałem Marszałka Żymierskiego, „Życie Olsztyńskie” 1948, nr 47 , s. 3. 
chomieniu przystani dla kajaków i łodzi z potrzebną wodniakom szatnią i bufetem. Ubolewać jedynie należało, że z przyjętych zobowiązań wywiązywano się tylko częściowo. Powodem takiego stanu rzeczy był niedostateczny dostęp do kredytów.

Wiosną 1948 roku, do Wydziału Komunikacyjnego, spływały już informacje, jako odpowiedzi na zarządzenie wojewody, w sprawie stanu infrastruktury przydatnej do dalszego rozwoju. Nie były one szczególnie satysfakcjonujące, ale postęp był widoczny. Oprócz znanych już i wykorzystywanych w poprzednich latach schronisk, starostowie, na nowy sezon zarezerwowali w hotelach, internatach, nadleśnictwach i majątkach państwowych dodatkowo blisko 300 miejsc noclegowych. Tak więc łącznie, do dyspozycji turystów na terenie Warmii i Mazur było ok. 1000 miejsc sypialnych o różnym standardzie ${ }^{33}$. Jednakże taki stan nie zadawalał nikogo, zwłaszcza, że w budżetach Urzędów Powiatowych nie było środków finansowych na utrzymanie i modernizację poczynionych rezerwacji. $\mathrm{Z}$ tego też względu Ministerstwo Ziem Odzyskanych, dysponując materiałami z lustracji, w porozumieniú z władzami terenowymi, przekazało PTK kolejne obiekty. Znajdowały się one w następujących miejscowościach: Barczewie, Zalesiu, Lalce, Mrągowie, Mikołajkach, Rynie, Węgorzewie, Orzyszu, Rucianach, Ostródzie, Jezioranach, Pluskach, Fromborku, Ornecie, Biskupcu i Lidzbarku Warmińskim. Po tej decyzji zarząd PTK posiadał już 20 obiektów turystyczno-wypoczynkowych ${ }^{34}$. Tuż przed nasileniem przyjazdów oddano jeszcze do dyspozycji gości schronisko w Świętej Lipce. Niepokoiły natomiast przeciągające się roboty budowlane w olsztyńskiej Wysokiej Bramie. Ku uciesze wielu wędrowców, w trakcie sezonu, uruchomiono jeszcze pięć kolejnych schronisk w najczęściej odwiedzanych miejscowościach: Mrągowie, Rucianach, Krutyni, Lidzbarku i Lalkowie nad jeziorem Łańskim. Brak miejsc noclegowych był tak dokuczliwy, że wyrażono nawet zgodę na utworzenie prywatnego pensjonatu. W Krutyni prowadziła go autochtonka Grodecka. Zachęceni pierwszą ratą kredytu inwestycyjnego w kwocie 3100000 złotych, zaradni działacze PTK typowali też kolejne obiekty $\mathrm{w}$ uroczych miejscowościach regionu do dalszych remontów ${ }^{35}$. Na ukończeniu były już prace w podobnych obiektach w Ostródzie, Fromborku, Węgorzewie i Piszu. Z inicjatywy inż. Zubelewicza zadbano także o niezbędne przybyszom informacje. Na Dworcu Głównym w odnowionej tablicy zamieszczono przydatny turystom Plan Miasta. Uruchomiono także biura informacji dla potrzebujących w: lokalu PTK przy ulicy Bałtyckiej, PBP „Orbis” mieszczącym się przy ulicy Stalina, Referacie Turystyki Wydziału Komunikacyjnego

${ }^{33}$ U progu nowego sezonu ruch turystyczny na Warmii i Mazurach zapowiada się imponująco, „Życie Olsztyńskie" 1948, nr 82, s. 3.

34 Dwadzieścia obiektów turystyczno wypoczynkowych posiada już PTK na Warmii i Mazurach, Życie Olsztyńskie" 1948, nr 91, s. 3.

3514 schronisk i domów wypoczynkowych, oto z czym rozpoczyna nowy sezon na Warmii i Mazurach Polskie Tow. Krajoznawcze, „Życie Olsztyńskie”1948, nr 101, s. 3. 
(Ratusz) oraz w Dyrekcji Okręgowej Kolei Państwowych przy Alei Zwycięstwa. Podobny punkt przewidywano w Wysokiej Bramie, gdzie prace remontowe były już na ukończeniu. Pocieszającym był także fakt oddania do użytku podróżnych, nowego dworca, wraz z poczekalnią, Państwowej Komunikacji Samochodowej przy ulicy Partyzantów. Do dyspozycji podróżnych było jeszcze osiem dorożek konnych i zaledwie dwie taksówki. W tym czasie dzięki dużemu zaangażowaniu Z. Kowalczyka powstał także Oddział Powiatowy PTK w Ostródzie, a obowiązki prezesa sprawował tam Henryk Perzanowski ${ }^{36}$.

Po trzyletniej kadencji, zgodnie z zapisami statutu, na Walnym Zebraniu członków, dokonano także wyboru nowego zarządu WMZT. Tworzyli go: T. Jesionowski, A. Kierc, C. Zawadzki, R. Zawadzki, W. Siwiński, S. Smotrycki i S. Żbikowski. Zebrani zaszczytną funkcję prezesa ponownie powierzyli J. Wodzińskiemu ${ }^{37}$. Organizacje propagujące rozwój turystyki poszerzały społeczne wpływy i tak jak cały region zyskiwały na znaczeniu. Dobrym tego przykładem były ukazujące się także pochlebne artykuły zamieszczone m. in. w: „Dzienniku Ludowym” nr 89, "Rzeczypospolitej” nr 103, w dodatku do „Robotnika” nr 105 oraz w tygodniku „Odra” propagujące walory i rozwijającą się infrastrukturę regionu. W podobnej tonacji na łamach „Odrodzenia” wypowiadał się także Jerzy Putrament. Coraz ciekawsze wystawy, dzięki zapobiegliwości kustosza Skurpskiego prezentowało również Muzeum Mazurskie. Z tego też powodu, w dniu 8 maja, do Olsztyna przybyła blisko 500 osobowa wycieczka przedstawicieli Szkolnych Kół Krajoznawczo Turystycznych, kończących ogólnopolski zjazd w Warszawie. Władze partyjno-państwowe wykorzystały ten fakt, jako tubę propagandową, chcąc uwypuklić proces zagospodarowania Ziem Północnych pod rządami komunistów. Młodych działaczy na dworcu głównym oczekiwał wraz z harcerską orkiestrą, specjalnie powołany Komitet Powitalny. Fakty natomiast były smutne. W przejętych przez organizacje turystyczne kilkudziesięciu obiektach, działalność prowadziło jedynie pięć schronisk, co znacznie ograniczało przyjazdy wycieczkowiczów. W pozostałych lokalach brakowało łóżek, pościeli, wyposażenia kuchennego itp. Przeciągały się też prace adaptacyjne. Głównie z tych powodów Warmię i Mazury odwiedziło mniej turystów niż się spodziewano. Nawet w reprezentacyjnej olsztyńskiej Wysokiej Bramie remont i to tylko częściowo zakończono dopiero w listopadzie 1948 roku. Oddano wówczas do użytku przylegający do niej budynek. Umożliwiło to przeniesienie z ulicy Bałtyckiej biura zarządu PTK, uruchomienie wspomnianego punktu informacji turystycznej oraz urządzenie 3 pokoi gościnnych. Na pierwszym piętrze przygotowywano sale: odczytową, konferencyjną a także czytelnię i biblio-

\footnotetext{
36 Z. Wójcik, op. cit., s. 43.

37 Ibidem, s. 43.
} 
tekę. Piętro kolejne wyposażano w sprzęt na dużą salę sypialną dla grup zorganizowanych ${ }^{38}$. Mimo braku miejsc noclegowych prowadzono akcje reklamowe. Członkowie WMZT rozmiłowani w sztuce fotografowania wykonali szereg interesujących zdjęć w terenie. Posłużyły one do zaprezentowania w ramach przygotowanej przez Zarząd Główny PTK wystawy „Piękno Ziem Odzyskanych w fotografii”, działu o Warmii i Mazurach. Prezentowana w okresie zimy, w salach olsztyńskiego Muzeum Mazurskiego ekspozycja, była pierwszym etapem przygotowań do sezonu turystycznego w roku 1949. Interesującym był też fakt, że już w lutym zbiory przekazane zostały do Gdańska. Władze w Olsztynie do zagadnień promocyjnych przywiązywały coraz większą uwagę. Dostrzegły też słuszną potrzebę, umożliwienia zakupu, odwiedzającym region, wyrobów pamiątkarskich. W tym celu Wydział Kultury i Sztuki Urzędu Wojewódzkiego w porozumieniu z Izbą Rzemieślniczą rozpisał konkurs na najciekawsze i atrakcyjne reklamówki. Pomysłodawcom i producentom zagwarantowano nawet nagrody i wyróżnienia. Kierując się potrzebą ochrony krajobrazu i przyrody, podjęto pracé, nad wydaniem albumu z roślinami będącymi pod ochroną. Bogata historia tych ziem oraz obfitość przyrodniczych atrakcji powodowały duży napływ wczasowiczów i turystów. Przyjęcie wszystkich zainteresowanych uniemożliwiała fatalna baza noclegowa. Aby choć częściowo rozwiązać ten problem, zobligowano Kuratorium Olsztyńskiego Okręgu Szkolnego, do utworzenia w okresie wakacji, w placówkach oświatowych, sieci Szkolnych Schronisk Młodzieżowych, w najczęściej odwiedzanych miejscowościach ${ }^{39}$. Natomiast Dyrekcja Okręgowa Kolei Państwowych na bocznicach w Ostródzie, Giżycku i Węgorzewie podstawiła przystosowane na potrzeby tzw. „wczasów rodzinnych” wagony kolejowe. Przyszłościowo, problem ten postanowiono rozwiązać, poprzez uwzględnienie $\mathrm{w}$ planie 6-letnim, programu rozwoju infrastruktury turystycznej, opracowanego przez PTK. Zakładał on powiększenie, za kwotę 150 milionów, sieci schronisk do 30. Pozwolić to miało na przyjęcie jednocześnie dwóch tysięcy osób $^{40}$. Z uwagi na powyższe oraz niespotykane gdzie indziej warunki przyrodnicze, Zarząd Główny PTK, zlecił oddziałowi olsztyńskiemu, organizację sekcji turystyki wodnej. Podkreślić należy, że niecodzienną atrakcją na Warmii i Mazurach były nie tylko szlaki wielkich jeziorach. Przykładowo, nad rzeką Pasłęką, w Nadleśnictwie Kudypy, znajdował się rezerwat bobrów, uznawanych w tamtym czasie za

38 Olsztyn zaprasza turystów. Sala konferencyjna i pokoje gościnne w PTK - gotowe, „Życie Olsztyńskie” 1948 , nr 325, s. 3.

39 Schroniska młodzieżowe projektowano otworzyć w następujących miejscowościach: Frombork - 40 miejsc (dalej m), Giżycko - 60 m, Mikołajki - 40 m, Olsztyn - 40 m, Orzysz - 30 m, Ostróda - 40 m, Pisz - 25 m, Węgorzewo - $40 \mathrm{~m}$, Szczytno - $40 \mathrm{~m}$. Opłaty za nocleg wynosiły: 70 złotych za pierwszą noc, a za następne 30 złotych. Aby umożliwić szerszą dostępność w jednej miejscowości zamieszkać można było najwyżej 3 dni. (Zob. Sieć schronisk turystycznych organizuje dla młodzieży olsztyńskiej Kuratorium, „Życie Olsztyńskie” 1949, nr 78, s. 6)

40 Ziemia warmińsko-mazurska najżywotniej interesuje turystykę polską, „Życie Olsztyńskie” 1949, nr 163, s. 4. 
gatunek wymierający. Jednakże mieszkańcy Warmii i Mazur, zainteresowani byli także poznaniem innych części kraju. W okresie zimy 1949 roku Fundusz Wczasów Pracowniczych (FWP), po raz pierwszy, przyznał olsztyńskiej Okręgowej Komisji Związków Zawodowych 101 miejsc w ośrodkach wypoczynkowych Dolnego Śląska, tj. w: Dusznikach, Cieplicach, Świeradowie, Lądku, Kudowie i Polanicy. Dodatkowo, 72 miejsca, mieszkańcy województwa mogli wykorzystać w Krynicy Górskiej, Szczawnicy i Jastrzębiu Zdroju oraz Busku i Ciechocinku, gdzie zarezerwowanych było łącznie 54 miejsca $^{41}$. Lansowana przez FWP forma wypoczynku zyskiwała szybko na popularności, dlatego jeszcze przed sezonem urlopowym, Centralna Komisja Związków Zawodowych, przejęła do swoich zasobów, ośrodek Wojewódzkiego Związku Samorządowego w Rucianem. Ponadto, zarząd Oddziału PTK, podpisał z FWP umowę na obsługę 28 grup wycieczkowych, w ramach tzW. „WCZasów ruchomych"42. Ich niewątpliwą zaletą było zapewnienie wyżywienia i noclegu wczasowiczom, wadą natomiast trzykrotna konieczność zmiany zakwaterowania w trakcie dwutygodniowego turnusu i pełna kontrola nad wypoczywającymi gośćmi. Innowacyjne przedsięwzięcie, zmotywowało prezesa Zarządu Głównego PTK S. Leszyckiego, do przyjazdu na Warmię i Mazury w celu oceny stanu przygotowań ilustracji obiektów. Zasobność FWP w środki finansowe umożliwiała lepsze doposażenie infrastruktury turystycznej, ale do zapewnienia przyzwoitego poziomu wypoczynku, zabieg ten, okazał się niewystarczający. W trosce o wycieczkowiczów, PTK, przejęło wiosną od Wydziału Osiedleńczego okazały budynek we Fromborku, z przeznaczeniem na kolejne, blisko 100 osobowe schronisko. Cały region sukcesywnie zyskiwał na znaczeniu. Wraz z nowym rozkładem jazdy pojawiły się dogodniejsze połączenia kolejowe z Gdańskiem, Warszawą i Wrocławiem. Na początku sezonu turystycznego, na Warmii i Mazurach, funkcjonowało 16 schronisk PTK, 1 WMZT, 4 schroniska młodzieżowe i tyleż domów wypoczynkowych FWP. W Polsce natomiast schronisk turystycznych było ledwie $66^{43}$.

Z uwagi na wzrastającą popularność regionu, zarząd Główny PTK, postanowił, że Ogólnopolskie Walne Zebranie Sprawozdawczo-Wyborcze towarzystwa odbędzie się właśnie w Olsztynie 17 czerwca 1949 roku. Poprzedziło je wyznaczone na dzień wcześniej ostatnie posiedzenie zarządu, które odbyło się w sali konferencyjnej oddziału olsztyńskiego, w lokalu, przy ulicy Wysokiej Bramy. W tym właśnie

${ }^{41}$ Z. Wójcik, op. cit. s. 45.

42 „Wczasy ruchome” były próbą racjonalnego wykorzystanie skromnej bazy noclegowej. Organizowano je w terminie od 1 czerwca do 30 września. Każda z 28 grup po 50 osób przebywała na Warmii i Mazurach na dwutygodniowych turnusach i w tym czasie, co kilka dni zmieniała miejsce pobytu. Wypoczynek rozpoczynał się w Olsztynie, następnie przemieszczano się szlakiem: Ruciany, Mikołajki, Wilkasy zwiedzając okolicę i zatrzymując się na nocleg w funkcjonujących przy szlaku schroniskach PTK. (Zob. A. Chmiel, op. cit., s. 255; 1400 turystów na wczasach ruchomych zwiedzi najpiękniejsze okolice naszego regionu, „Życie Olsztyńskie” 1949, nr 99, s. 4).

43 A. Chmiel, op. cit., s. 255; Turystyka Warmii i Mazur zyskuje w kraju na popularności i znaczeniu, „Życie Olsztyńskie” 1949, nr 162, s. 6. 
dniu przybyli na Warmię: prezes PTK S. Leszczycki, jego zastępca K. Staszewski, sekretarz zarządu głównego W. Kowalski oraz członkowie R. Pleszerowa i dyrektor biura Z. Tokarski. Natomiast delegaci walnego zgromadzenia obradowali w świetlicy gmachu Teatru im. Stefana Jaracza. Było to duże wydarzenie w historii miasta, ponieważ w obradach, uczestniczył m.in. wicemarszałek sejmu Stanisław Szwalbe, poseł i były wojewoda Bogdan Wilamowski oraz przedstawiciele Zrzeszenia Samopomocy Chłopskiej, Ligi Morskiej, Polskiego Towarzystwa Tatrzańskiego i Polskiego Związku Narciarskiego. Już w wystąpieniu otwierającym obrady, prezes Leszczycki, wspomniał o podnoszonej niejednokrotnie koncepcji połączenia wszystkich organizacji zajmujących się krzewieniem turystyki w jedno towarzystwo, a w końcowej części przemówienia, za duży wkład pracy wyróżnił A. Zubelewicza złotą odznaką PTK. Po wygłoszeniu referatów programowych i dyskusji, w wyniku wyborów prezesem na kolejną kadencje ponownie wybrano S. Leszczyckiego ${ }^{44}$

Obecność w stolicy województwa znaných polityków i orędowników dalszego turystycznego zagospodarowania Warmii i Mazur, zainspirowała mieszczące się przy Alei Stalina 26 PBP „Orbis” do aktywniejszej działalności. Jej efektem była organizacja, dostępnych dla większości wycieczek, organizowanych w niedzielę i święta do atrakcyjnych miejscowości województwa. Przykładowo wyjazd do Bartąga (najtańszy) skalkulowano na 60 złotych, a wyprawa do Pisza, jako najdroższa kosztowała 460 złotych. Podobną działalność prowadziła także Okręgowa Rada Związków Zawodowych (ORZZ), która na wzór centrali powołała przy swojej siedzibie Komisję Krajoznawcząa ${ }^{45}$. Zmiany zaszły także we władzach Oddziału PTK. Krótko przed inauguracją kolejnego sezonu turystycznego, obowiązki prezesa obją kompetentny i lubiany w tym środowisku Aleksander Zubelewicz. Przybywało też wycieczek i obozów sportowych z głębi kraju. Aby jeszcze bardziej rozreklamować okolicę, Wydział Turystyki Ministerstwa Komunikacji, zorganizował w okresie wakacji, wycieczkę dla referentów zajmujących się tą problematyką w Urzędach Wojewódzkich. Ekspedycją kierował znany krajoznawca Mieczysław Orłowicz. Pomysłowością wykazał się także olsztyński Oddział PTK, jako, że z inicjatywy jego działaczy, ukazały się w sprzedaży karty pocztowe z godłami miast Warmii i Mazur. Równie pocieszającym był fakt, że w Ostródzie dobrze rozwijał się zakład produkujący łodzie i kajaki dla miłośników wypraw wodnych. Sezon turystyczny roku 1949

44 Pełny skład zarządu przedstawiał się następująco: wiceprezesi - M. Arczyński; członkowie - K. Jasiński, J. Kołodziejczyk, S. Lenartowicz, J. Witkiewicz, W. Żukowski; sekretarz - K. Staszewski; z-ca sekretarza W. Kowalski; skarbnik - A. Dobrowolski; z-ca T. Nawrocki; członkowie - S. Cieślikowska, R. Fleszer, S. Herbart, J. Henner, S. Jarosz, J. Jurosz, A. Langer, W. Milata, Z. Nawrocki, M. Orłowicz, W. Pietraszkiewicz, S. Szymański, L. Węgrzynowicz, J. Wojsznis i K. Wyszomirski. Powołano także Komisję Rewizyjną, którą tworzyli: Z. Beczkowicz, K. Czerwiński, W. Gruszczyński, J. Kołodziejski, S. Osiecki i Z. Wołowska. (Zob. Z. Wójcik, op. cit., s. 47).

45 A. Chmiel, op. cit., s. 255. 
był najbardziej udanym z dotychczasowych. Sprawdziła się w praktyce lansowana przez ORZZ formuła tzw. „wczasów ruchomych”, choć urlopowiczów było o ok. 30 $\%$ mniej niż zakładano.

Na przyszły sezon planowano już w ramach tej koncepcji drugi szlak przez Ostródę, Iławę, Elbląg i Frombork. Statek pasażerski kursujący po Kanale Warmińskim (Ostródzko-Elbląskim) przewiózł łącznie 3872 wycieczkowiczów, a w hotelu „Orbis” w Giżycku, od maja do polowy sierpnia, mieszkało 2200 osób. W piętnastu schroniska PTK ${ }^{46}$ (715 lóżek) i jednym WMZT w Olsztynie przy ulicy Bałtyckiej, w ramach wczasów ruchomych, przyjęto łącznie 29550 wędrowców ${ }^{47}$. Zauważyć jednak należy, że wielu turystów zwiedzało Warmię i Mazury indywidualnie. W okresie letnim, na łonie natury, funkcjonowały też liczne obozy harcerskie, a w placówkach oświatowych kolonie dzieci i młodzieży. Na wczasach przebywały tu także rzesze związkowców w ramach FWP. Niemniej jednak niewielka ilość miejsc noclegowych, barów i restauracji uniemożliwiały przyjęcie większej ilości zainteresowanych bliższym poznaniem tej krainy. Nieprzypadkowo więc, w jednym Z artykułów prasowych, zamieszczonym we wrześniu na łamach „Życia Olsztyńskiego" napisano wprost: „Faktem jest bezspornym, że ponad $50 \%$ przybyłych np. do Giżycka turystów nie mogło się w nim zatrzymać z uwagi na brak pomieszczeń. Znacznie jednak gorzej sprawy te kształtowały się np. Węgorzewie, które wprawdzie posiada schronisko PTK obliczone na 100 łóżek, za to żadnej przyzwoitej restauracji. W Piszu i Mikołajkach to samo" ${ }^{48}$.

Kierownictwo olsztyńskiego Oddziału PTK kierując się faktem, że problem ten z uwagi na wcześniejszą lustrację terenu znany był prezesowi Leszczyckiemu, wystąpiło do Zarządu Głównego PTK z wnioskiem o pomoc w rozwiązaniu powyższych problemów. Przewidywania działaczy - wynikające także z wcześniejszych sugestii przybyłych na zjazd delegatów - okazały się całkiem słuszne, bo już jesienią uruchomiono na ten cel kredyt w kwocie 12 milionów złotych, z przeznaczeniem na dalszą odbudowę i remonty nowych obiektów i 8 milionów, na zakup wyposażenia ${ }^{49}$. Dużo większy kłopot stanowił brak hoteli dla bardziej wymagającego wędrowcy. W większości miast regionu ich po prostu nie było a te istniejące

46 Olsztyński Oddział PTK w roku 1949 posiadał schroniska w następujących miejscowościach: Olsztynie (Wysoka Brama), Fromborku, Kętrzynie, Krutyni, Lidzbarku Warmińskim, Lalce-na półwyspie jeziora Łańskiego, Mikołajkach, Mrągowie, Orzyszu, Piszu, Piławkach k. Ostródy, Rucianem, Świętej Lipce, Węgorzewie, Wilkasach k. Giżycka. Łącznie było w nich jedynie 715 miejsc noclegowych. Tylko nieliczne schroniska posiadały zaplecze kuchenne. (Zob. Przygotowania do nowego sezonu wczasów i turystyki, „Życie Olsztyńskie” 1950, nr 56, s. 6).

47 Ibidem, s. 6.

48 Po sezonie turystycznym na Warmii i Mazurach, „Życie Olsztyńskie” 1949, nr 267, s. 5.

49 Z otrzymanego kredytu 2,8 mil. przekazano na odbudowę Schroniska nr 2 w Piławkach pod Ostródą, 1250000 tys. na remont Schroniska nr 2 w Wilkasach, 800 tys. na remont Hotelu Turystycznego w Ornecie. Z pozostałej kwoty postanowiono odnowić schroniska w Kętrzynie, Krutyni, Fromborku oraz Wysokich Bram w Olsztynie i Pasłęku. (Zob. Odbudowa i wyposażenie schronisk turystycznych $z$ dodatkowego kredytu 12 milionów złotych, „Życie Olsztyńskie” 1949, nr 273, s. 6). 
w Braniewie, Iławie, Kętrzynie, Morągu, Ostródzie, Pasłęku i Reszlu najczęściej nie posiadały udrożnionej kanalizacji, brakowało w nich wody, elektryczności, czystej pościeli itp. Poza znanym i chętnie odwiedzanym Giżyckiem, w wymienionych placówkach, najczęściej panował najogólniej rzecz ujmując bałagan, odstraszający gości. Jeszcze w schyłkowym okresie lat czterdziestych problem ten pozostawał nierozwiązany. Mimo to piechurów wciąż przybywało. Z grona olsztyńskich wędrowców wyróżniali się późniejsi przewodnicy, tj. Czesław Herman z małżonką Haliną. Wywodzili się z inteligencji kresowej i jak wielu innych, należeli do zagorzałych zwolenników turystyki pieszej.

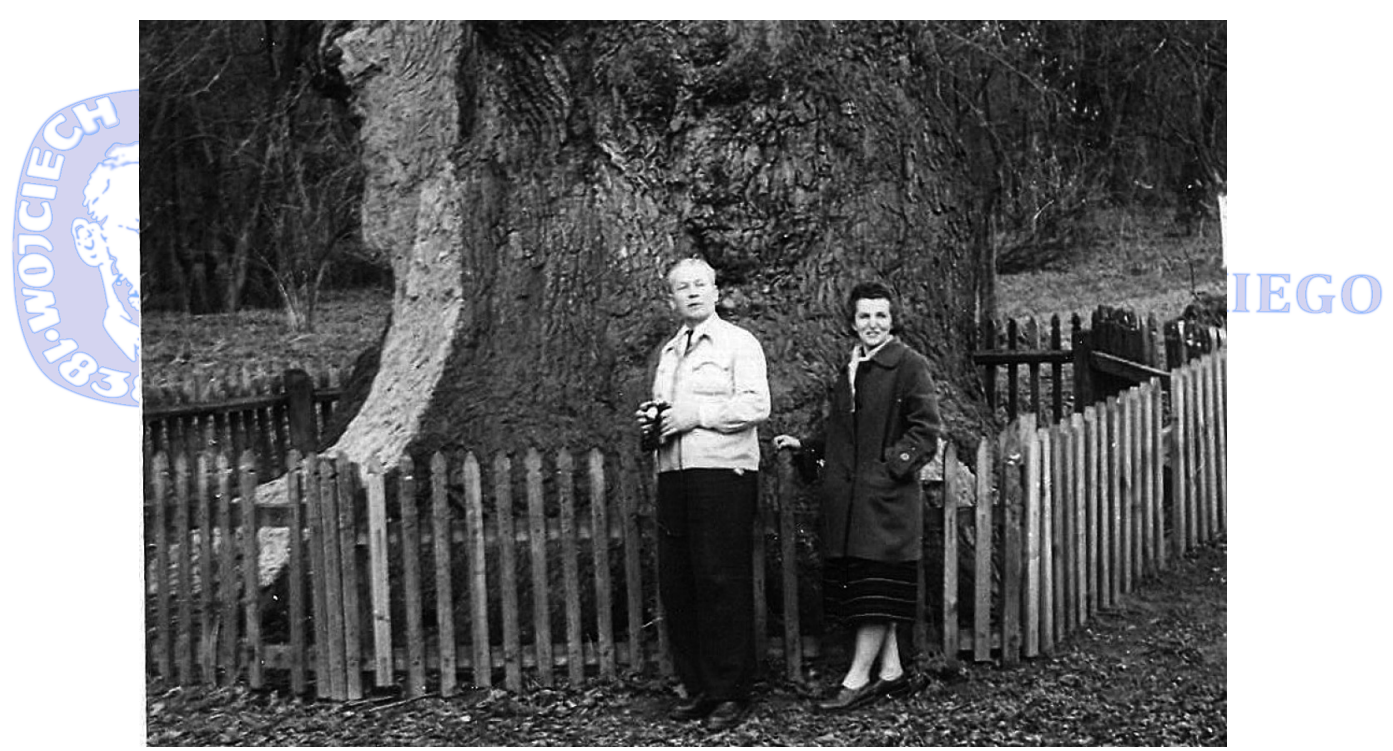

Fot. 2. Widok z końcowej dekady lat czterdziestych. Czesław i Halina Herman zwiedzają Kadyny w gminie Tolkmicko. Na drugim planie okazały dąb, jako ówczesny pomnik przyrody. Źródło: Z prywatnych zbiorów H. Herman.

Kłopoty związane z bazą noclegową, na terenie województwa częściowo kompensował rozwój sieci placówek FWP, koordynowany przez możnego mecenasa, jakim była Centralna Rada Związków Zawodowych. W tym czasie po raz pierwszy zwrócono uwagę na potrzebę budowania kortów tenisowych, boisk do siatkówki itp. urządzeń przydatnych w rekreacji. W roku 1950, olsztyńskie PTK, koordynujące ruch turystyczny w regionie, postanowiło wycieczkowiczów nie objętych wczasami ruchomymi, kierować do schronisk usytuowanych poza dwoma szlakami, przeznaczonymi dla ich uczestników. Miało to odciążyć przepełnione w latach poprzednich domy noclegowe na tych trasach i zatrzymać gości w regio- 
nie. Jednakże takie rozwiązanie sprawiało przybyszom wiele trudności, ponieważ w przygotowanych dla nich schroniskach na szlaku Olsztyn - Lidzbark - Kętrzyn - Wilkasy - Węgorzewo nie było zaplecza kuchennego, a na dodatek, miejscowości te, znajdowały się w zasadzie poza popularnymi, wielkimi jeziorami mazurskimi. Wdrożenie tej koncepcji nie rozwiązało zasadniczo problemu. W drugiej połowie sierpnia, w Rucianem, tłok był tak wielki, że na bocznicy kolejowej ustawiono szereg wagonów, przystosowanych do prowizorycznych noclegów ${ }^{50}$. Coraz powszechniej, nadzieje, na właściwą rozbudowę infrastruktury w województwie olsztyńskim, pokładano $\mathrm{w}$ zapowiadanym połączeniu instytucji zajmujących się propagowaniem turystyki, w jedną organizację. W dniu 17 grudnia odbył się w Warszawie zapowiadany zjazd zjednoczeniowy z Polskim Towarzystwem Tatrzańskim ${ }^{51}$. Podłożem tej decyzji były wpływy ideologii stalinowskiej zarzucające obu towarzystwom „przesycenie elementem inteligenckim i drobnomieszczańskim, niepotrafiącym jeszcze przełamać starych tradycji i powiązać się z klasą pracującą ${ }^{52}$. Znamienne słowa wypowiedziano w Warszawie, na pierwszym pósiedzeniu Rady Turystycznej, której pracami kierował Włodzimierz Reczek. Był to czas przemian i wzorowania się na rozwiązaniach radzieckich. Identycznie postąpiono z ruchem sportowym, rozwiązując dobrze funkcjonujące na terenie kraju związki sportowe.

Kiedy opadły już nieco emocje, 27 lutego 1951 roku, odbył się w Olsztynie, Okręgowy Zjazd Aktywu Polskiego Towarzystwa Turystyczno Krajoznawczego (PTTK). Przybywających na obrady działaczy witał transparent nawiązujący treścią do panującego $\mathrm{w}$ tamtych latach politycznego klimatu: „Aktyw turystyczny i krajoznawczy w pierwszym szeregu walki o wykonanie Planu 6-letniego". W wyniku przeprowadzonych wówczas wyborów prezesem Zarządu Okręgowego PTTK został wywodzący się z ORZZ Krzeszowski. Funkcję wiceprezesów, powierzono zasłużonym $\mathrm{w}$ dotychczasowym propagowani walorów regionu Zubelewiczowi oraz związanemu ze środowiskiem oświatowym Wiśniewskiemu. Stanowisko sekretarza przypadło Olkowskiemu ${ }^{53}$. Rozpoczął się nowy etap rozwoju ruchu turystyczno-krajoznawczego na Warmii i Mazurach, a jego głównym zadaniem, była budowa struktur terenowych powstałego towarzystwa.

50 Ruchome wczasy wagonowe w Rucianach, „Życie Olsztyńskie” 1950, nr 213, s. 4.

${ }_{51}$ M. Arczyński, Powstanie Polskiego Towarzystwa Turystyczno-Krajoznawczego i jego działalność w latach 1950-1956, w: PTTK w XX-leciu PRL, Warszawa 1967, s. 60.

52 Archiwum Polskiej Akademii Nauk, III-92, j. 409, Protokół pierwszego posiedzenia Rady Turystycznej z dnia 2 marca 1950 r. Ministerstwo Komunikacji, Warszawa, k. 69.

53 Nowe formy turystyki, „Życie Olsztyńskie” 1951, nr 59, s. 6. 


\section{Podsumowanie}

Odziedziczone po poprzednich mieszkańcach regionu tradycje i ocalała częściowo infrastruktura, były inspiracją do wskrzeszenia działalności turystyczno-rekreacyjnej w Okręgu Mazurskim. Niespotykana radość z zakończenia wojny i entuzjazm dostrzegany wśród wielu osiedleńców stały się impulsem wielu późniejszych przedsięwzięć. Z powyższych względów już jesienią 1945 roku zawiązał się w Olsztynie Warmińsko-Mazurski Związek Turystyczny. Adaptacja usytuowanego przy ulicy Bałtyckiej poniemieckiego baraku na pierwsze w regionie Schronisko Turystyczne okazała się równie silnym bodźcem do dalszego rozwoju. Władze administracyjne wiązały z tym procesem duże nadzieje, a dowodem na powyższe był osobisty udział Zygmunta Robla, Pełnomocnika Rządu na Okręg Mazurski (późniejszego wojewody) w zorganizowanej w Olsztynie wiosną 1946 roku konferencji poświęconej przyszłości ruchu turystycznego. W zainicjowany proces dobrze wpisało się też powołanie w dniu 20 maja 1946 roku w przyszłej stolicy regionu oddziału Polskiego Towarzystwa Krajoznawczego. Powyższe przedsięwzięcia były silnym fundamentem do dalszego rozwoju, który swoim autorytetem czynnie wspierała m. in. miejscowa działaczka i poetka Emilia Sukertowa-Biedrawina. Niecodzienne zaangażowanie pierwszych entuzjastów, stworzyło warunki do zwiedzenia Warmii i Mazur 30 tysiącom wędrowców już w roku 1946. W latach następnych ciągle ich przybywało, a zjawisko to mobilizowało działaczy i władze administracyjne do systematycznej poprawy bazy noclegowej i warunków wypoczynku. Dlatego bliższym poznaniem Ziem Odzyskanych interesowali się także wysocy urzędnicy administracji państwowej. Ich obecność stwarzała miejscowym włodarzom dogodniejsze warunki w dostępie do kredytów inwestycyjnych.

Walory przyrodnicze i klimatyczne regionu inspirowały także do zainteresowania się łyżwiarstwem, bojerami, wędkarstwem lodowym i myślistwem. Znacznym utrudnieniem w rozwoju rekreacji była natomiast wspomniana już niedostateczna ilość miejsc noclegowych. W roku 1948 do dyspozycji wędrowców było jedynie ok. 1000 miejsc sypialnych ${ }^{54}$. Z powyższych względów władze komunistyczne zmuszone były zaakceptować funkcjonowanie pensjonatów prywatnych. Przybywających w te strony nie zrażał nawet fakt, że w stolicy województwa było jedynie kilka dorożek konnych i zaledwie dwie taksówki. Trudności w dostępie do materiałów i brak specjalistów skutkowały opóźnieniem w zakończeniu prac budowlanych w reprezentacyjnej Wysokiej Bramie. Remont atrakcyjnego obiektu zakończono dopiero pod koniec wspomnianego 1948 roku. Z uwagi na niedostateczną ilość schronisk i hoteli, wczasowiczów lokowano nawet w zaadoptowanych

54 U progu nowego sezonu ..., s. 3. 
na te potrzeby wagonach kolejowych podstawianych na bocznicach najczęściej odwiedzanych miast ${ }^{55}$. Zapóźnienia te znacząco ograniczały większe zainteresowanie regionem.

Poprawy w obsłudze ruchu turystycznego upatrywano w lansowanej przez władze Polskiej Rzeczypospolitej Ludowej reorganizacji struktur i powołaniu jednej, centralnie sterowanej organizacji. Jednakże wcześniejsze zaniedbania i niedoinwestowanie, przekraczały możliwości organizacyjne powstałego w roku 1950 Polskiego Towarzystwa Turystyczno-Krajoznawczego.

\section{Zbigniew Wójcik, Anfänge des touristischenVerkehrs in Ermland und Masuren (1945-1951)}

Zusammenfassung

Touristische Traditionen, die in Ostpreußen angefangen wurden, wurden nach der Bildung im Jahre 1945 von Okręg Mazurski [deutsch: Masurischer Bezirk] von neuen Bewohnern dieser Enklave fortgeführt. Trotz der großen Zerstörung und des Austausches der Bevölkerung wurde schon im Herbst Warmińsko-Mazurski Związek Turystyczny [deutsch: Ermlandisch-Masurischer Touristenverband] berufen. Die Aktivisten der neu gegründeten Organisation sicherten mit der Begeisterung und dem Enthusiasmus die unversehrte Infrastruktur, eröffneten Jugendherbergen und verbreiteten Naturvorteile der Region. Im Frühling nächstes Jahres wurde aus einer Eingebung von Mieczysław Orłowicz heraus die Abteilung von Polskie Towarzystwo Krajoznawcze (PTK) [deutsch: Polnische Gesellschaft für Heimatkunde] gegeründet. Das ermöglichte, die alte materielle Basis zu übernehmen und zu renovieren sowie allmählich eine Organisationsstruktur zu bauen. Nachfolgend danach wurden Ermland und Masuren von vielen Touristen und Wassersportlern besucht. Unter ihnen gab es auch Staatsbeamten hohen Ranges und die Generalität. Daraus folgte eine gute Promotion der zahlreichen Attraktionen der Woiwodschaft Olszyn. Der Prozeß der weiteren Entwicklung erleichterten Investitionskredite. In Anbetracht dessen, dass die heimischen Aktivisten sehr effektiv waren, entschied der Hauptvorstand von PTK [Abkürzung von „Polnische Gesellschaft für Heimatkunde"-Anm. d. Übrs.], im Jahre 1949 die Gesamtpolnische Hauptversammlung in Olsztyn zu organisieren. Dann wurde zum ersten Mal über eine baldige Vereinigung von Polskie Towarzystwo Tatrzańskie [deutsch: Polnische Tatra-Gesellschaft] mit Polskie Towarzystwo Krajoznawcze [deutsch: Polnische Gesellschaft für Heimatkunde] gesprochen. Erst am 27. Februar 1951 fand jedoch in der Hauptstadt der Region das Bezirkstreffen des Aktivs von Polskie Towarzystwo Turystyczno-Krajoznawcze [deutsch: Polnische Gesellschaft für Touristik und Heimatkunde] statt.

Übersetzt von Zbigniew Wójcik

\section{Zbigniew Wójcik, The beginnings of tourism in Warmia and Masuria (1945-1951)}

\section{Summary}

Tourist traditions were initiated in East Prussia and continued by new residents of this enclave after the creation of Mazury District in 1945. Despite the massive destruction and population exchange, Warmia and Masurian Tourist Association was established in the autumn. Activists of the newly formed organization secured the remaining infrastructure with zeal and enthusiasm, they launched shelters and promoted the natural values of the region. In the spring of the following year, inspired by Mieczyslaw Orłowicz, a branch of the Polish Touring Association (PTK) was formed in Olsztyn. This enabled the acquisition and renovation of the former material base and the gradual building of the organizational structure. In the wake of this, Warmia and Masuria was visited by many tourists and boaters. Among them there were also senior government officials and generals. This resulted in a good promotion of the numerous attractions of Olsztyn voivodeship. The process facilitated the further devel-

55 Z. Wójcik, op. cit., s. 45. 
opment of investment loans. In 1949, due to the high efficiency of local activists, the Main Board of PTK decided to organise the National General Assembly Election in Olsztyn. Then, for the first time there were made proposals of the imminent unification of the Polish Tatra Assosiation with the Polish Touring Assosiation (PTK). However, until the $27^{\text {th }}$ February 1951 there was held the District Tourist Association Congress of the Polish Active Members in the regional capital

Translated by Zbigniew Wójcik

Dr Zbigniew Wójcik

Katedra Turystyki, Rekreacji i Ekologii

Uniwersytet Warmińsko-Mazurski

zbigniew-wojcik@o2.pl

\section{Źródła archiwalne}

Archiwum Polskiej Akademii Nauk

III-92, j. 409, Protokół pierwszego posiedzenia Rady Turystycznej z dnia 2 marca 1950 r. Ministerstwo Komunikacji, Warszawa, k. 69.

\section{Prace doktorskie}

Siwicki Marek

2011 Edukacyjna działalność młodzieżowych ośrodków żeglarskich na Warmii i Mazurach w tatach 1945-1989. Studium historyczno-pedagogiczne, UWM Olsztyn.

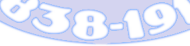

\section{Opracowania}

Andrusikiewicz Anna

1986 Przewodnictwo turystyczne na Warmii i Mazurach, w: Przewodnictwo turystyczne w Polsce, WarszawaKraków, ss. 162-168.

Andrusikiewicz Anna

2002 Poznaj swój kraj i region, w: Kalendarz Olsztyna 2002, Olsztyn, ss. 206-213.

Arczyński Marek

1967 Powstanie Polskiego Towarzystwa Turystyczno-Krajoznawczego i jego działalność w latach 1950-1956, w: PTTK w XX-leciu PRL, Warszawa, ss. 59-90.

Browiński Czesław

1974 Olsztyn 1945-1970, Olsztyn.

Chmiel Aleksy

2007 Turystyka w Polsce w latach 1945-1989, Warszawa.

Dönhoff Marion

1988 Kindheit in Ostpreußen by Marion Gräfin Dönhoff, München.

Gąsiorowski Andrzej

2005 Podróże historyczne I krajoznawcze na pograniczu pruskim 1466-1939, Olsztyn.

Jaczewski Zdzisław

1964 Walory turystyczno-krajoznawcze województwa, Rocznik Olsztyński, t. VI, Olsztyn, ss. 363-383. 
Orłowicz Mieczysław

1991 Ilustrowany przewodnik po Mazurach Pruskich $i$ Warmii, Olsztyn.

Wójcik Zbigniew

2007 Starożytnym traktem przez Warmię i Mazury, w: Szkice Humanistyczne, nr 1-2, Olsztyn, ss. 197-206.

Wójcik Zbigniew

2014 Turystyka, rekreacja i sport w Lidzbarku Warmińskim w czasach Polski Ludowej, Olsztyn.

\section{Artykuły prasowe}

Arkona

1945/1946 Uroczystości Kopernikowskie we Fromborku, t. 1, nr 8, s. 20.

Wiadomości Mazurskie

1946 Warmia i Mazury terenem turystyki, nr 112, s. 3.

1946 Olsztyński Klub Motocyklowy wśród huku piorunów rozpoczął swoją działalność, nr 159, s. 4.

Zycie Olsztyńskie

1947 Drugie schronisko turystyczne uruchomione będzie w Olsztynie, nr 16, s. 3.

1947 Turystyka na Warmii i Mazurach pod znakiem zapytania zpowodu braku pomieszczeń, nr 19, s. 3.

1947 Cos dla turystyki. Nowe połaczenia wodne, nr 19, s. 4.

1947 Na jeziorach mazurskich ruszyty statki pasażerskie, $\mathrm{nr}$ 24, s. 4.

1947 Min. Kaczorowski spędził święta w woj. olsztyńskim, nr 27, s. 3.

19471000 harcerzy olsztyńskich i 2 tysiące harcerzy-gości rozbije wkrótce namioty, nr 43, s. 3.

1947 66-procentowe znizki wzmoga turystykę na Warmii i Mazurach, nr 67, s. 3.

1947 Wielka wycieczka asów polskiej turystyki, nr 80, s. 3.

1947500 tysięcy złotych - największa dotację w Polsce otrzymało PTK w Olsztynie, nr 105, s. 3.

1947 Pięćdziesiąt tysięcy osób, oto bilans ruchu turystycznego $w$ bieżącym sezonie letnim $w$ województwie olsztyńskim, nr 121, s. 3.

1948 Wielkie polowanie w lasach mazurskich z udziałem Marszałka Żymierskiego, nr 47, s. 3.

1948 U progu nowego sezonu ruch turystyczny na Warmii i Mazurach zapowiada się imponująco, nr 82, s. 3.

1948 Dwadzieścia obiektów turystyczno wypoczynkowych posiada już PTK na Warmii i Mazurach, nr 91, s. 3.

194814 schronisk i domów wypoczynkowych, oto z czym rozpoczyna nowy sezon na Warmii i Mazurach Polskie Tow. Krajoznawcze, nr 101, s. 3.

1948 Olsztyn zaprasza turystów. Sala konferencyjna i pokoje gościnne w PTK-gotowe, nr 325, s. 3.

1949 Sieć schronisk turystycznych organizuje dla młodzieży olsztyńskiej Kuratorium, nr 78, s. 6.

19491400 turystów na wczasach ruchomych zwiedzi najpiękniejsze okolice naszego regionu, nr 99, s. 4.

1949 Turystyka Warmii i Mazur zyskuje w kraju na popularności i znaczeniu, nr 162, s. 6.

1949 Ziemia warmińsko-mazursaka najżywotniej interesuje turystykę polską, nr 163, s. 4.

1949 Po sezonie turystycznym na Warmii i Mazurach, nr 267, s. 5.

1949 Odbudowa i wyposażenie schronisk turystycznych z dodatkowego kredytu 12 milionów złotych, nr 273, s. 6.

1950 Przygotowania do nowego sezonu wczasów i turystyki, nr 56, s. 6.

1950 Ruchome wczasy wagonowe w Rucianach, nr 213, s. 4.

1951 Nowe formy turystyki, 1951, nr 59, s. 6. 